Jahangirnagar University J. Biol. Sci. 8(1): 57-65, 2019 (June)

\title{
Study of an arsenic metabolizing bacteria from arsenic contaminated soil of Chandpur district, Bangladesh
}

\author{
Roksana Khanam ${ }^{1}$, Ripa Moni, Md. Zahidul Islam, Md. Morsaline Billah ${ }^{2}$, \\ Umme Salma Zohora, Farah Sabrin ${ }^{1}$ and Mohammad Shahedur Rahman * \\ Department of Biotechnology and Genetic Engineering, Jahangirnagar University, Savar, \\ Dhaka-1342, Bangladesh
}

\begin{abstract}
Arsenic is a toxic metal found as inorganic oxyanion arsenate As(V) and arsenite As (III) species. The disposal of toxic heavy metals such as arsenic poses high risk to environment. The present study was undertaken to isolate arsenic-metabolizing bacteria from arsenic contaminated soil of Chandpur district, which is one of the most arsenic contaminated area in Bangladesh and later these bacteria were screened for their ability to metabolize arsenate. Out of ninety eight isolates, ten were found to be capable of metabolizing arsenic in Yeast Extract Mannitol (YEM) medium containing $2 \mathrm{mM}$ arsenate at $37^{\circ} \mathrm{C}$. One of the bacterial isolates designated as I-25 was found to produce an extracellular enzyme which can reduce As(V) into As(III) and able to grow in presence of up to $500 \mathrm{mM}$ arsenate. Subsequent molecular identification of this enzyme producing bacterial isolate using 16s rRNA sequence analysis was correlated with previously identified isolate as Bacillus aryabhatti. Further characterization of the enzyme showed that optimum $\mathrm{pH}$ of the extracellular enzyme by the bacterial species was 7 and optimum temperature for the enzyme activity was $60^{\circ} \mathrm{C}$. The bacterial isolates can be exploited for the study of possible bioremediation of arsenic contamination.
\end{abstract}

Key words: Arsenic metabolizing bacteria, Bacillus aryabhattai, Bangladesh

\section{INTRODUCTION}

Arsenic is one of the world's most notorious poison. Consumption of arsenic contaminated water and plants grown on arsenic-contaminated soils can lead to arsenic toxicosis in animals and melanosis, gangrene, cancer and ultimately death in humans. It is a natural toxic element released into the environment by natural phenomenon (geogenic) or by anthropogenic activities (Cullen \& Reimer, 1989). Arsenic contamination in ground water and irrigation fields is a serious problem in many parts of the world, especially in Bangladesh. It exists both in toxic inorganic and comparatively less toxic organic species in the environments. The most common species of inorganic arsenic are trivalent arsenite [As (III)] and pentavalent arsenate [As(V)]. Mitigation of As (III) from soil and groundwater is of great challenge and due to its higher toxicity and mobility than As (V).

1 Department of Biotechnology and Genetic Engineering, Mawlana Bhashani Science and Technology University, Santosh, Tangail-1902, Bangladesh

2 Biotechnology and Genetic Engineering Discipline, Khulna University, Khulna-9208, Bangladesh

*Corresponding author. E-mail: rahmanms@juniv.edu 
Arsenite can bind to sulfhydryl groups of proteins and dithiols such as glutaredoxin. On the other hand, arsenate is a chemical analog of phosphate and can inhibit oxidative phosphorylation (Ordonez et al., 2005). It may interfere with the DNA repair system or DNA methylation state, inhibition of p53 and telomerase activities (Chou et al., 2001; Wang et al., 2001), oxidative stress, promotion of cell proliferation and signal transduction pathways leading to the activation of transcription factors (Wu et al., 1999). In addition, it has been found that arsenic induces DNA damage via the production of reactive oxygen species (Matsui et al., 1999).

Although arsenic is generally toxic to life, microorganisms can use arsenic compounds as electron donors, electron acceptors or show arsenic detoxification mechanisms (Ahmann et al., 1994). The bacteria which possess the ability to convert arsenate to arsenite are of environmental significance due to the formation of uncharged $\left(\mathrm{H}_{3} \mathrm{AsO}_{3}\right)$ state which has higher mobility than arsenate. Arsenic mobility in natural environment is a major concern in arsenic-rich and contaminated areas. Dissimilatory arsenate reduction bacteria (DARB) may be involved in the solubilization, fate and transport of arsenic by reducing arsenate to arsenite (Ahmann et al., 1994).

Wide varieties of microorganisms are capable of growth in presence of heavy metal ions and can tolerate high concentrations (Nies, 1992; Gaballa \& Helmann, 2003; Rehman et al., 2007). It has been reported that the strains of Aeromonas, Exiguobacterium, Acinetobacter, Bacillus and Pseudomonas that can tolerate high concentrations of arsenic up to $100 \mathrm{mM}$ arsenate or up to $20 \mathrm{mM}$ arsenite (Anderson \& Cook (2004). The heavy metals are present in the environment naturally; therefore, microorganisms have evolved mechanisms to resist their toxic effects (White \& Gadd, 1986). Various bacteria such as Acidithiobacillus, Bacillus, Deinococcus, Desulfitobacterium and Pseudomonas have been reported to be resistant to arsenic (Cervantes et al., 1994; Oremland et al., 2001; DeVicente et al., 1990; Dopson et al., 2001; Niggemyer et al., 2001; Suresh et al., 2004).

A variety of microorganisms (iron and sulfur reducing bacteria) are known to play an important role in the biochemical cycle of arsenic, through its conversion with different solubility, mobility, bioavailability and toxicity (Silver \& Phung, 2005). Arsenite (the reduced form) is more toxic and more soluble than arsenate, which is relatively insoluble, non-bioavailable compounds. Speciation of arsenic is controlled by not only oxidation and reduction processes, but also by methylation, and adsorption to other particles (Aurilio et al., 1994). Bacteria, fungi, ciliates, algae, mosses, macrophytes and higher plants have several mechanisms for the conversion and removal of arsenic and other heavy metals (Holan \& Volesky, 1994; Rehman et al., 2007).

The present study reports $B$. aryabhatti with the ability to metabolize arsenic and reduce As (V) into As (III) for the first time in Bangladesh. This B. aryabhatti has been previously identified and reported by our group to produce various extracellular enzymes such as $\alpha$-amylases, cellulases, $\beta$-glucosidases, lipases and proteases (Rahman et al., 2018). However, the ability of this bacterium for arsenic metabolizing activity was never reported and there had been no report about the presence of this bacterium in arsenic 
contaminated samples. The present study also investigates optimization temperature, $\mathrm{pH}$ and optimum arsenate concentration for maximum arsenate reduction for the extracellular enzyme produced by this bacterium.

\section{MATERIALS AND METHODS}

Sample collection: Soil sample was collected from Saharasti upazilla of Chandpur district, Bangladesh. Sample from subsurface soil $(0-15 \mathrm{~cm}$ in depth) were collected, placed in plastic bag and kept on ice or at $4^{\circ} \mathrm{C}$ until further analysis.

Chemicals and stock solutions: All buffers and solutions were prepared with distilled water and sterilized by autoclaving at $121^{\circ} \mathrm{C}$ for $30 \mathrm{~min}$. As(III) stock solutions $(10 \mathrm{mM})$ were prepared from stock sodium arsenite $\left(\mathrm{NaAsO}_{2}\right)$ and $\mathrm{As}(\mathrm{V})$ solutions $(10 \mathrm{mM})$ from sodium arsenate heptahydrate $\left(\mathrm{Na}_{2} \mathrm{HAsO}_{4} \cdot 7 \mathrm{H}_{2} \mathrm{O}\right)$. Stock solutions were stored at $4^{\circ} \mathrm{C}$ in the dark. A starch-iodine complex (mixture of aqueous starch and Lugol's iodine solution) was prepared freshly before use.

Bacterial culture preparation and identification of isolate: For the bacterial culture preparation, $1 \mathrm{~g}$ of each soil sample was taken in $100 \mathrm{~mL}$ of $0.1 \mathrm{M}$ phosphate buffer solution and mixed well by vortexing for $3 \mathrm{~min}$. Each sample was serially diluted with sterile saline water and plated on Yeast Extract Mannitol (YEM) agar medium. After $16 \mathrm{~h}$ of incubation, stocks were prepared by dissolving the culture in equal volume with $40 \%$ glycerol. After single colony isolation, the morphological, biochemical and molecular characteristics of the isolated bacterial strains were also evaluated as previously described by Rahman et al. (2018).

Screening of arsenic metabolizing Bacteria: Precultures were prepared from each single colony in $5 \mathrm{~mL}$ YEM (without arsenate) broth and incubated at $37^{\circ} \mathrm{C}$ for $24 \mathrm{~h}$ at $120 \mathrm{rpm}$. Then preculture was centrifuged, washed twice with sterile buffer solution and resuspended in $2 \mathrm{~mL}$ sterile water. Twenty $\mu \mathrm{L}$ preculture was inoculated into YEM broth medium containing $2 \mathrm{mM}$ arsenate and incubated under the above condition. Then cultures were centrifuged at $10,000 \times \mathrm{g}$ for $5 \mathrm{~min}$ and supernatant was taken for further analysis. Next, $1 \mathrm{~mL}$ of supernatant was added into test tube followed by addition of 30 $\mu \mathrm{L}$ of starch-iodine complex (Mandal et al., 2007). The test tubes were incubated in dark for $10 \mathrm{~min}$. Then optical density (OD) was measured by using spectrophotometer (Mecasys Optizen Pop UV/Vis Spectrophotometer, Korea) and highly active bacteria were identified from these bacterial isolates.

Identification of localization of the active enzyme: Firstly, 24 hours cultures were grown in YEM medium which contained arsenate. Then they were subjected to centrifugation at $10000 \times \mathrm{g}$ for $5 \mathrm{~min}$ and supernatant was removed. Pellet was washed twice with autoclaved phosphate buffer. Then the pellet was resuspended into $1 \mathrm{~mL}$ of autoclaved YEM medium (without arsenate). $100 \mu \mathrm{L}$ of resuspended aliquots were inoculated into autoclaved $5 \mathrm{~mL}$ YEM medium (without arsenate) for $24 \mathrm{~h}$ shaking at $37^{\circ} \mathrm{C}, 120 \mathrm{rpm}$. After $24 \mathrm{~h}$ of incubation, the tubes were centrifuged and supernatant (4 $\mathrm{mL}$ ) was taken into another autoclaved test tubes. Then $1 \mathrm{~mL}$ arsenate $(10 \mathrm{mM})$ was added into $4 \mathrm{~mL}$ of supernatant. After $2 \mathrm{~h}$ of incubation in shaking water bath $\left(37^{\circ} \mathrm{C}, 120\right.$ 
rpm), $2 \mathrm{~mL}$ supernatant was withdrawn and $60 \mu \mathrm{L}$ starch-iodine complex was added into it and incubated in dark. If color change occurred, the enzyme responsible for arsenic metabolism was considered as extracellular one.

In the event of no color change, sonication was used for cell disruption. In this case, pellets were washed twice with autoclaved buffer solution by centrifugation at $10000 \times \mathrm{g}$ for $2 \mathrm{~min}$. Then supernatant was aspirated and the pellet was dissolved into $2 \mathrm{~mL}$ autoclaved YEM medium. Then the cells were disrupted by using ultrasonicator at $37^{\circ} \mathrm{C}$ for $3 \mathrm{~h}$. After sonication, Lugol's iodine was added and incubated in dark. Color change indicated that the enzyme responsible for arsenic metabolism was intracellular one.

Determination of optimum metabolizing condition: For determining the optimum growth of the bacterial strains, different arsenate concentrations $(0 \mathrm{mM}, 2 \mathrm{mM}, 16 \mathrm{mM}$, $64 \mathrm{mM}, 128 \mathrm{mM}, 250 \mathrm{mM}$ and $500 \mathrm{mM}$ ) in YEM medium were considered in different test tubes and autoclaved at $121^{\circ} \mathrm{C}$ for $30 \mathrm{~min}$. Then freshly prepared bacterial culture inoculated into these concentrations and incubated for $24 \mathrm{~h}$. Finally, the absorbance was measured at $600 \mathrm{~nm}$.

For optimization of the temperature requirement on enzyme activity, large amount of supernatant were used. For this, $100 \mathrm{~mL} 2 \mathrm{mM}$ arsenate containing YEM medium were prepared in a conical flask with $50 \mathrm{~mL}$ medium. Then the flask was autoclaved at $121^{\circ} \mathrm{C}$ for $30 \mathrm{~min}$ and $500 \mu \mathrm{L}$ of freshly prepared bacterial culture was inoculated into each flask. After $24 \mathrm{~h}$ incubation, $10 \mathrm{~mL}$ of culture was taken into $15 \mathrm{~mL}$ falcon tube and centrifuged at $10,000 \times \mathrm{g}$ for $20 \mathrm{~min}$. Then supernatant was collected into test tubes $(5$ $\mathrm{mL}$ each) and stored at $-20^{\circ} \mathrm{C}$. Test tubes were kept in different temperatures $\left(30^{\circ} \mathrm{C}, 40^{\circ} \mathrm{C}\right.$, $50^{\circ} \mathrm{C}, 60^{\circ} \mathrm{C}, 70^{\circ} \mathrm{C}, 80^{\circ} \mathrm{C}$ and $90^{\circ} \mathrm{C}$ ) for $10 \mathrm{~min}$ and then cooled at room temperature. Finally starch iodine complex was added and after an incubation period, optical density was measured at $580 \mathrm{~nm}$ using spectrophotometer.

\section{RESULTS AND DISCUSSION}

Screening of arsenic metabolizing bacteria: For the first instance, 98 bacterial isolates was isolated from arsenic contaminated soil samples and it was found that 40 bacterial strains were able to grow in presence of arsenic. However, ten isolates showed arsenic metabolizing ability and only four strains designated as I-3, I-6, I-25, and I-112, respectively showed higher arsenic metabolizing activity of all. In all cases, soil samples were cultured into YEM medium which contained $2 \mathrm{mM}$ arsenate and starch iodine complex was used as an indicator for growth. Among the different isolates, I-25 is found to be a novel arsenic metabolizing strain that was previously identified as B. aryabhatti according to the morphological, biochemical and molecular characteristics as reported earlier. In addition to that the ability of this strain to produce $\alpha$-amylases, cellulases, $\beta$ glucosidases, lipases and proteases was reported before by our group (Rahman et al., 2018). In the present investigation, the bacterial species B. aryabhatti showed highly active arsenic metabolizing activity as it was able to change the color of starch iodine complex within 5 min of incubation at dark condition. 
Screening for arsenate reductase activity: Four isolates (I-3, I-6, I-25, and I-112) were able to convert arsenate into arsenite in which, it broke up the $\mathrm{I}_{5}{ }^{-}$of starch Lugol's iodine complex into iodine and iodide and resulted in disappearance of blue color. It indicated the presence of arsenate reductase enzyme in the supernatant. Among the 4 arsenate reducing bacterial isolates, I-25 (i.e. B. aryabhattai) was found to be the most potent (Fig. 1 and Fig. 2). Here, positive and negative controls were sodium arsenite and sodium arsenate respectively.
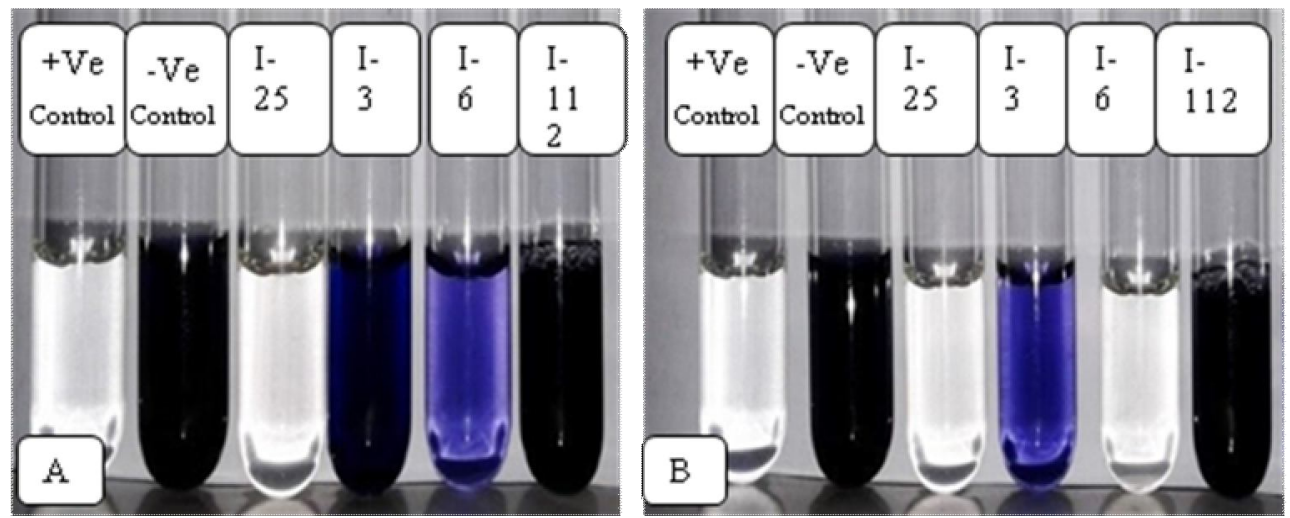

Fig. 1. Induction mechanism for arsenic metabolizing bacteria (A. Screening before conversion of arsenate into arsenite. B. Screening result after $10 \mathrm{~min}$ )

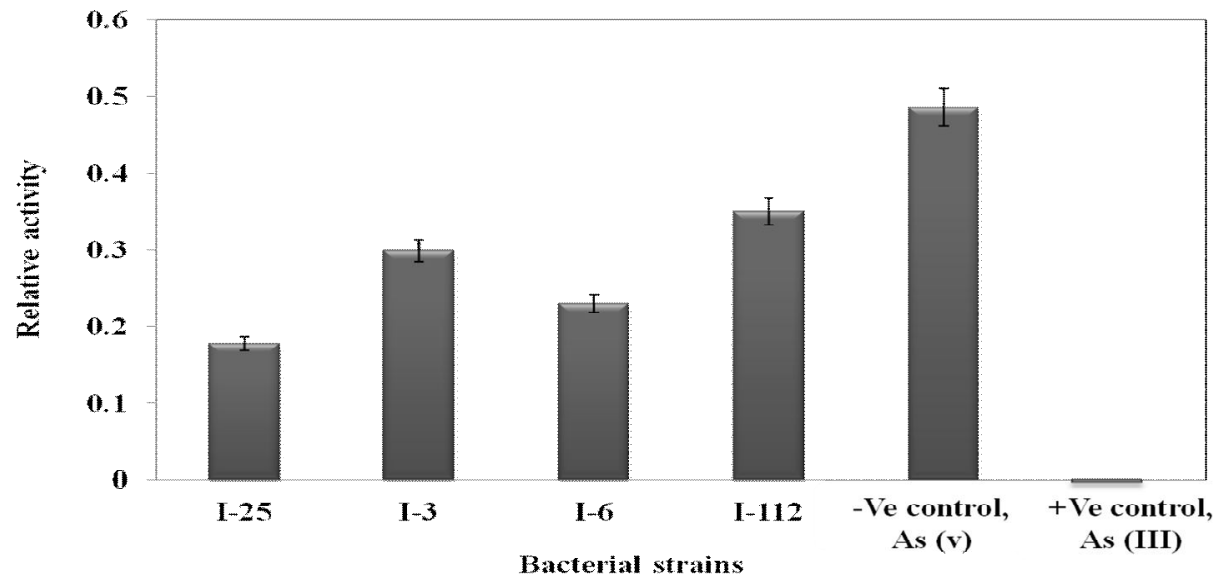

Fig. 2. Screening of the most potent arsenate reducing bacteria $(n \geq 3)$ 
Localization of active enzyme: The enzyme produced by the bacterial isolate I-25 (i.e. B. aryabhattai) was extracellular in nature and it was interpreted that it contained arsenate reducing enzyme. It was because of the fact that the supernatant of the isolate was able to reduce starch-iodine complex and produced a colorless compound from a colored product (Fig. 3) where as pellets did not show any change in color after the addition of the starchiodine complex (Fig. 4).
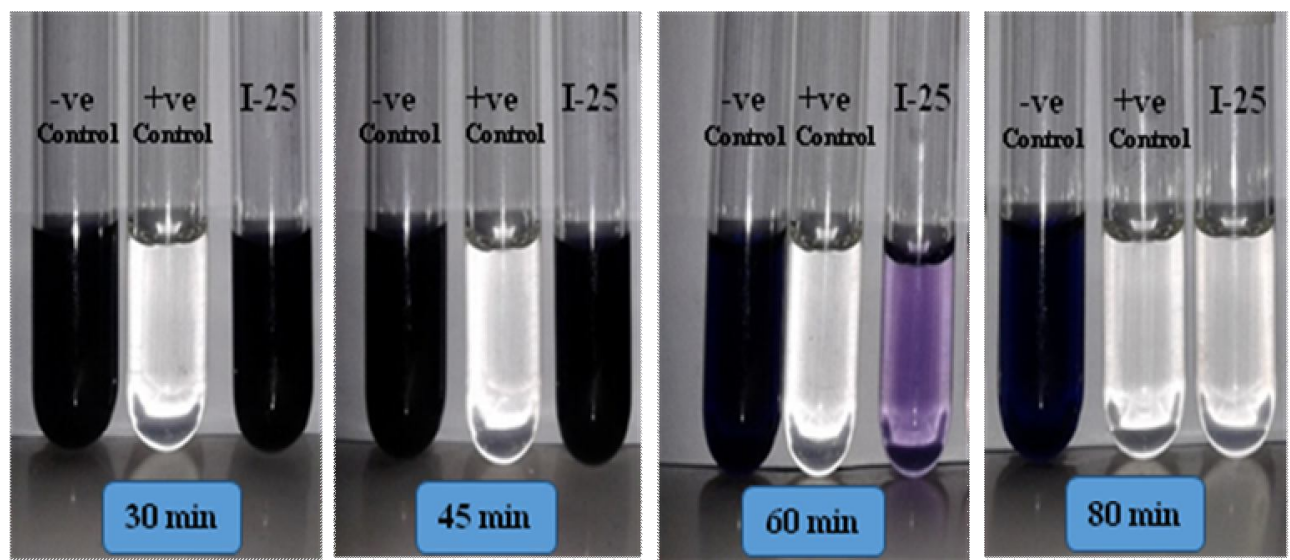

Fig. 3. Effect of supernatant activity on starch iodine complex reagent
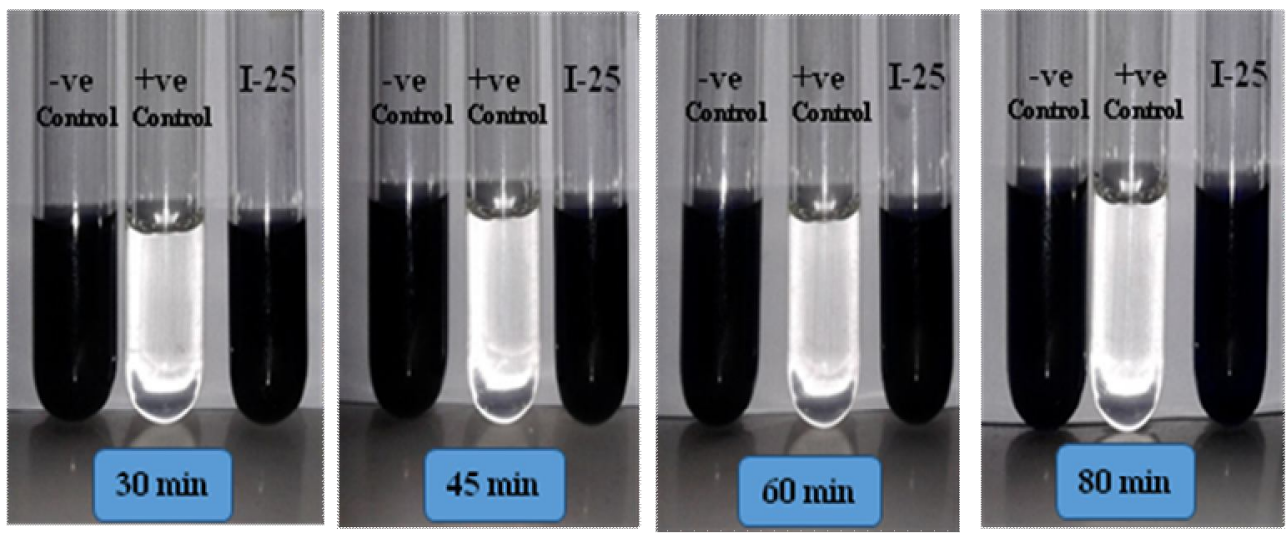

Fig. 4. Effect of cell (pellet) activity on starch iodine complex reagent

Determination of optimum metabolizing conditions: For arsenic metabolizing strains of $B$. aryabhattai, optimum arsenate concentration was between 64-128 mM. Higher OD gives the higher arsenate concentration on bacterial growth (Fig. 5). Optimum temperature on arsenate reducing enzyme was $60{ }^{\circ} \mathrm{C}$. In this case lower OD indicated higher effect of temperature on bacterial enzyme activity (Fig. 6) and could tolerate about $500 \mathrm{mM}$ arsenate on bacterial growth. 


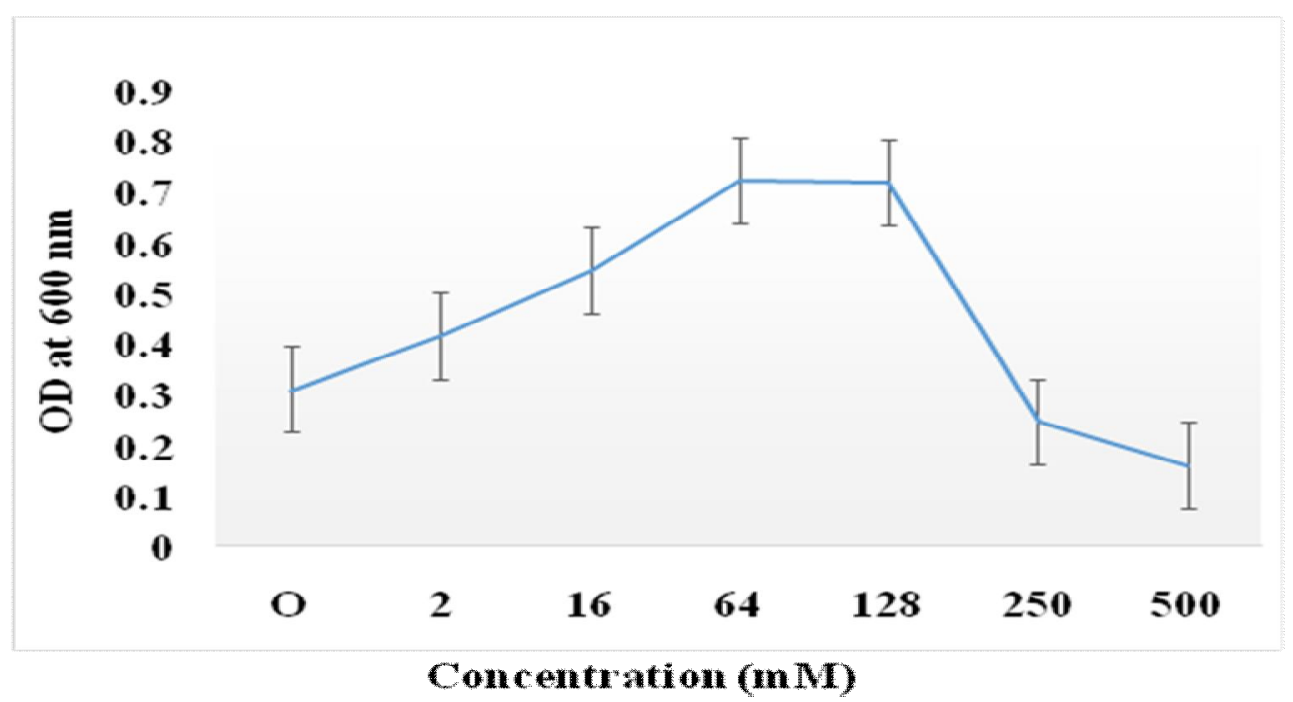

Fig. 5. Effect of optimum arsenate concentration on bacterial growth

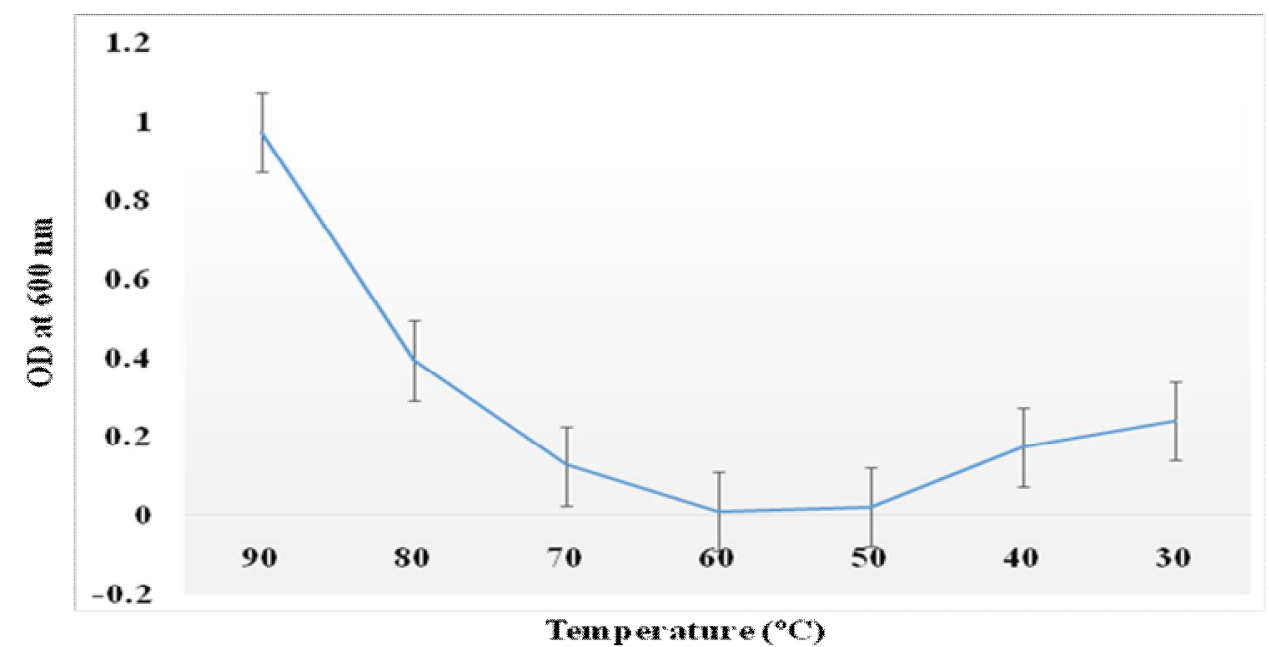

Fig. 6. Effect of temperature on enzyme activity of bacterial isolates growing in YEM medium

The screening method of this study is simple, rapid, cost effective and reliable compare with other methods such as HG-AAS, ICP-MS or ICP-AES (Mandal et al., 2007). This technique is easy to perform, and the reagents and equipment are readily available in most of the laboratories. In this study, the arsenic-metabolizing bacterial isolate was identified as $B$. aryabhattai based on phylogenetic analysis of $16 \mathrm{~S}$ rRNA sequence. During the present investigation $B$. aryabhattai could tolerate As (V) up to $500 \mathrm{mM}$ on their growth at $\mathrm{pH}$ 7.0. During the present investigation, the enzyme of B. aryabhattai showed the 
ability to reduce As (V) into As (III). It seems counter-intuitive to convert a less toxic compound to a more toxic form, but arsenate activity is closely coupled with efflux from the cells so that intracellular arsenite never accumulates (Shakoori et al., 2010).

This study provides insight into identification, levels of arsenic resistance and reduction of arsenate by novel bacterial isolates which could play an important role in arsenic cycling in the arsenic-contaminated soils in Bangladesh. Isolated bacteria from arsenic contaminated soil were capable of metabolizing arsenic from the culture media. Highly As (V) resistant isolates could be a excellent candidate for the study of arsenic bioremediation. Further research is necessary to explore the possibility to use these bacteria in the other culture conditions to remove arsenic from the contaminated soil.

\section{REFERENCES}

Ahmann, D., Krumholz, L.R., Hemond, H.F., Lovely, D.R. and Morel, F.M.M. 1997. Microbial mobilization of arsenic from sediments of the aberjona watershed. Environ Sci Technol., 31: 2923-2930.

Ahmann, D., Roberts, A.L., Krumholz, L.R. and Morel, F.M.M. 1994. Microbe grows by reducing arsenic. Nature, 371: 750.

Aurilio, A.C., Mason, R.P. and Hemond, H.F. 1994. Speciation and fate of arsenic in three lakes of the Aberjona watershed. Environ Sci Technol., 28: 577-585.

Cervantes, C, Ji G., Ramirez, J.L. and Silver, S. 1994. Resistance to arsenic compounds in microorganisms. FEMS Microbiol Rev.,15: 355-367.

Chou, W.C., Hawkins, A.L., Barrett, J.F., Griffin, C.A. and Dang, C.V. 2001. Arsenic inhibition of telomerase transcription leads to genetic instability. J Clin Invest., 108: 1541-1547.

Cullen, W.R. and Reimer, K.J. 1989. Arsenic speciation in the environment. Chem Rev.,89: 713764.

De-Vicente, A., Aviles, M., Codina, J.C., Borrego, J.J. and Romero, P. 1990. Resistance toantibiotics and heavy metals of Pseudomonas aeruginosa isolated from natural waters. J Appl Bacteriol, 68: 625-632.

Dopson, M., Lindstrom, E.B. and Hallberg, K.B. 2001. Chromosomally encoded arsenical resistance of the moderately Thermophilic Acidophile Acidithio bacilluscaldus. Extremophiles., 5: 247-255.

Shakoori, F.R., Aziz, I., Rehman, A. and Shakoori, A.R. 2010. Isolation and Characterization of Arsenic Reducing Bacteria from Industrial Effluents and their Potential Use in Bioremediation of Wastewater. Pakistan J Zool., 42(3): 331-338.

Gaballa, A. and Helmann, J.D. 2003. Bacillus subtilis cpx-type ATPases: Characterization of Cd, $\mathrm{Zn}, \mathrm{Co}$ and $\mathrm{Cu}$ efflux systems. Biometals., 16: 497-505.

Holan, Z.R. and Volesky, B. 1995. Accumulation of Cd, lead and nickel by fungal and wood biosorbents. Appl BiochemBiotechnol., 53: 133-146.

Mandal, S.M., Mondal, K.C., Dey, S., Pati, B.R. 2007. A rapid colony screening method for the detection of arsenate-reducing bacteria. Indian J. Microbiol., 47:167-169.

Matsui, M., Nishigori, C., Toyokuni, S., Takada, J., Akaboshi, M., Ishikawa, M., Imamura, S. and Miyachi, Y. 1999. The role of oxidative DNA damage inhuman arsenic carcinogenesis: detection of 8-hydroxy-2'-deoxyguanosine in arsenic-related bowen's disease. J Invest Dermatol., 113: 26-31.

Nies, D.H. 1992. Resistance to Cadmium, Cobalt, Zinc and Nickel in microbes. Plasmid., 27: $17-$ 28. 
Niggemyer, A., Spring, S., Stackebrandt, E. and Rosenzweig, R.F. 2001. Isolation and characterization of a novel As (v)-reducing bacterium: implications for arsenic mobilization and the genus Desulfitobacterium. Appl Environ Microbiol., 67:5568-558.

Ordonez, E., Valbuena, N., Gil, J.A. and Mateos, L.M. 2005. Analysis of genes involved in arsenic resistance in Corynebacterium glutamicum ATCC 13032. Appl Environ Microbiol., 71: 6206-6215.

Oremland, R.S., Newman, D.K., Kail, B.W. and Stolz, J.F. 2001. Bacterial respiration of arsenate and its significance in the environment. Environmental chemistry of arsenic, CRC Press, Marcel Dekker Inc., New York, USA, 273-296.

Rahman, M.S., Banu, R., Moni, R., Islam, N., Ruma, M.K. and Zohora, U.S. 2018. Investigation on a Bangladeshi isolate Bacillus aryabhattai for promising biotechnological applications. Jahangirnagar University J. Biol. Sci., 7(2): 33-45.

Rehman, A., Ali, A., Muneer, B. and Shakoori, A.R. 2007. Resistance and biosorption of mercury by bacteria isolated from industrial effluents. Pakistan j Zool., 39: 137-146.

Silver, S. and Phung, L.T. 2005. Genes and enzymes involved in bacterial oxidation and reduction of inorganic arsenic. Appl Environ Microbiol., 71: 599- 608.

Suresh, K., Reddy, G.S.N., Sengupta, S. and Shivaji, S. 2004. Deinococcusindicus sp.Nov., an arsenic-resistant bacterium from an aquifer in west 65engal, India. Int.J Syst Evol Microbiol., 54: 457-461.

Wang, T.S., Hsu, T.Y., Chung, C.H., Wang, A.S., Bau, D.T. and Jan, K.Y. 2001. Arsenite induces oxidative DNA adducts and DNA-protein cross-links in mammalian cells. Free Radical Biol Med., 31: 321-330.

White, C. and Gadd, G. 1986. Uptake and cellular distribution of copper, cobalt and cadmium in strains of Saccharomyces cerevisiae cultured on elevated concentration of these metals. FEMS Microbiol Rev., 38: 227-283.

Wu, W., Graves, L.M., Jaspers, I., Devlin, R.B., Reed, W. and Samet, J.M. 1999. Activation of the EGF receptor signaling pathway in human airway epithelial cells exposed to metals. Am J Physiol., 277: 924-931. 